\title{
Soil Organic Carbon Stocks Assessment in Uttarakhand State using Remote Sensing and GIS Technique
}

\author{
Nitin Surendra Singh Gahlod, Navneet Jaryal*, Mallikarjun Roodagi, \\ Sanjay A. Dhale, Devinder Kumar and Ravindra Kulkarni
}

Soil and Land Use Survey of India, C - 4, sector - 1, Noida-201301

*Corresponding author

\begin{tabular}{|l|}
\hline K e y w o r d s \\
Bulk density \\
Models, Carbon \\
cycle, Carbon stock, \\
Pedotransfer \\
function, SOC stock \\
\hline Article Info \\
\hline $\begin{array}{l}\text { Accepted: } \\
\text { 12 December } 2018 \\
\text { Available Online: } \\
\text { 10 January } 2019\end{array}$ \\
\hline
\end{tabular}

\section{Keywords}

Bulk density Models, Carbon cycle, Carbon stock, Pedotransfer function, SOC stock

\section{A B S T R A C T}

\section{Introduction}

Greenhouse gases (GHGs) emission from anthropogenic activities is considered to be most significant driver of observed climate change since the mid- $20^{\text {th }}$ century. In annual report for the year 2017, National Centers for Environmental Information (NCEI) ref reported that global annual land surface temperature was $1.31^{\circ} \mathrm{C}$ above the $20^{\text {th }}$ century 
average and also the third highest in the 138year record, behind 2016 (warmest) and 2015 (second warmest). The global oceans also had their third warmest year since global records began in 1880 at $0.67^{\circ} \mathrm{C}\left(1.21^{\circ} \mathrm{F}\right)$ above the $20^{\text {th }}$ century average (Global Climate Report, 2017)

The resulting variability of climate poses threat to the environment and the quality of human life over the world. It is for this reason; the parties to the United Nations Frame Work Convention on Climate Change (UNFCCC) have undertaken a comprehensive exercise to address the issues of climate change adaptation and mitigation. For such an undertaking, the assessment and management of natural carbon sources and sinks has proven to be most vital and practical approach to regulate the level of GHGs in the atmosphere.

Systems involving vegetation act as carbon sinks due to their ability to sequester from atmospheric carbon to deep layers of soil profile. Atmospheric carbon can be sequestered in long-lived carbon pools of plant biomass both above and below ground or recalcitrant organic and inorganic carbon in soils and deeper subsurface environments.

Soil organic carbon (SOC) is the carbon held within soil organic constituents (i.e., products produced as dead plants and animals decompose and the soil microbial biomass). The SOC stock to $1 \mathrm{~m}$ depth ranges from 30 tons $\mathrm{C} / \mathrm{ha}$ in arid climates to 800 tons/ha in organic soils in cold regions, and a predominant range of 50 to 150 tons $\mathrm{C} / \mathrm{ha}$ (Lal, 2004). Soils are considered as the largest carbon reservoirs of the terrestrial carbon cycle storing $2344 \mathrm{Pg}(1 \mathrm{Pg}=1015 \mathrm{~g})$ of carbon (C) up to $3 \mathrm{~m}$ depth which is more than twice that in vegetation $(359 \mathrm{Pg})$ and atmosphere $(760 \mathrm{Pg})$ combined. The size of the soil organic matter pool is determined by the rate of input of fresh organic matter, the proportion of humified carbon and the rate of efflux of carbon (Lal, 2001). There is established link between soil quality and soil organic carbon (SOC) concentration and atmospheric carbon.

With this work, we aim to make an assessment of SOC stock in Uttarakhand state of India as a unit under different soils and landuse systems (with its extent on surface layer i.e. 25 $\mathrm{cm})$. Information on carbon status could aid in estimating carbon sequestration potential for this important but fragile ecosystem of Uttarakhand state, India. The information generated in this study will be useful for policy-makers and environmentalists for undertaking appropriate conservation plans.

\section{Materials and Methods}

\section{Study area}

Uttarakhand state is a part of the northwestern Himalayas bounded by Nepal in the East and Himachal Pradesh in the West while the northern boundary goes up to Tibet/China, whereas southern boundary extends into IndoGangetic plains. The state lies between $28^{\circ} 43^{\prime}$ and $31^{\circ} 27^{\prime} \mathrm{N}$ Latitude and $77^{\circ} 34^{\prime}$ and $81^{\circ}$ 02' E Longitude with total geographical area of 53,48,379 ha, out of which approximately $84.7 \%$ is mountainous. About $20.03 \%$ of total geographical area is under snow cover/glaciers and steep slopes. The major North Indian rivers - the Ganga and the Yamuna, originate from this region. Uttarakhand state covers 13 districts within two revenue divisions (Figure 1). Out of total geographical area, $41,48,338$ ha area was covered under this study while remaining 12,00,040 ha area was covered under miscellaneous landuse i.e. habitation, rockout crop, snow cover and waterbodies.

The climate of Uttarakhand state can be characterized as subtropical. Within the same catchment subtropical even tropical climate is 
often observed at the lower end of the watershed i.e. in valleys, while temperate climate prevails in the upper reaches of the stream. The mean annual rainfall varies from 1100 to $1600 \mathrm{~mm}$ with intensity ranging from drizzling to torrential rain. The rainfall is heavy and well distributed in from June to September the wet season accurse during these months, the rainfall is moderate during May and October and the rainfall is low during November to February.

\section{Soil resource mapping survey}

The study was conducted during 2010-12 in the state of Uttarakhand by Soil and Land Use Survey of India (SLUSI) using guidelines developed for Soil Resource Mapping. The area of interest was large, having high altitudinal variation and other biophysical factors such as climate, slope and topography that influence soil type and biomass accumulation (and therefore Soil mapping and C stocks assessed in stratified fashion), stratification was carried on the basis of altitude zones and random selection of sampling points on differences in slope, physiography and landuse/cover in order to reduce uncertainty. Development of data on 1:50,000 scale to the extent of the area of interest was done to design of an effective sampling procedure to depict extent of area.

Stratified sampling using remotely sensed LISS III (Spatial resolution $23.5 \mathrm{~m}$ ) satellite data based on differences in slope, physiography, altitude and land-use/cover collected randomly along the road side taking in to account remoteness/inaccessibility of region. Carbon accounting making use of stratified random sampling has the benefits when compared to a random sampling approach. In this case, stratification refers to the division of a heterogeneous landscape into distinct strata based on the carbon stock in the vegetation. The benefits of this method are: a. If the strata are well defined and internally homogeneous (relative to all areas of equal altitude zones), the number of samples required to achieve a specified accuracy of the mean is considerably smaller than with random sampling.

b. The method is more robust if the overall distribution does not follow a normal random distribution, but still assumes deviations from such a distribution within each stratum are manageable in carbon accounting, maps derived from remote sensing (or direct attributes at the unit or pixel scale) form the strata containing range of slopes, land use/ cover types. The LISS III data generally have higher precision on low carbon density landscapes and variations within high carbon density categories.

\section{Preparation and processing of samples}

In the laboratory, samples for $\mathrm{C}$ analysis were dried in a solar oven and then sieved first through $20 \mathrm{~mm}$ mesh and then through $2 \mathrm{~mm}$ mesh. The plant roots and other visible fractions were removed and a fraction of each specimen was ground and reduced to particles with maximum diameter of 50 microns before automatic chemical analysis. Samples for determination of bulk density were placed to dry in KR box in an electric oven at $105{ }^{\circ} \mathrm{C}$ for approximately 72 hours.

\section{Analysis of pH, total carbon content and particle size distribution}

Soil $\mathrm{pH}$ of the samples was determined in a soil water suspension $(1: 2.5)$ by $\mathrm{pH}$ meter using a glass electrode. Organic Carbon was estimated by Walkley and Black method (Jackson, 1973).

Particle size distribution (mechanical analysis) of soil sample was determined by Bouyoucos Hydrometer method (Bouyoucos, 1962). 


\section{Estimation of bulk density}

For agriculture and forest landuse system, selected samples were analyzed in laboratory for estimation of bulk density as per standard Keen Raczkowski box technique (Black, 1965).

The various cases reported in literature indicates that the bulk density is closely associated with soil physical and chemical properties and can be estimated using pedotransfer functions but the performances of pedotransfer functions varies when subjected to different soils and landuse systems. The majority of these studies support the recommendation to apply these functions with care and evaluate the best function for each soil conditions before further applications (Abdelbaki, 2016; Xu et al., 2015 and Kaur et al., 2002).

Many researchers have observed that the soil texture is the most significantly related soil property which is related to bulk density of soil due to which sand and clay are the most essential parameter used in most of the pedotransfer functions models (Kumar et al., 2009). The soil organic carbon is considered to be second after soil texture in governing the soil bulk density and is reported to have a significant but negative correlation with bulk density of soil (Chaudhari et al., 2013; Sakin, 2012; Sakin et al., 2011; Leifeld et al., 2005 and Morisada et al., 2004). Therefore, keeping these facts in mid, the physico-chemical characteristics of 130 samples analyzed in laboratory for agriculture and forest land use were used for estimation of bulk density through six different models based on pedotransfer functions selected form literature and the calculated bulk density of these three models were plotted in against the values of observed bulk density and plotted graphs were utilized to work out coefficient of determination $\left(\mathrm{R}^{2}\right.$ value), thereby validating the models as per mentioned in literature (Abdelbaki, 2016; Bernoux et al., 1998; Tomasella and Hodnett, 1998 and Benites et al., 2007).

The equations used to estimate the bulk density values from the aforesaid models are as under:

Model 1: Bulk Density $\left(\mathrm{kg} / \mathrm{dm}^{3}\right)=1.419$ $0.0037 \times$ clay $(\%)-0.061 \times$ carbon $(\%)$

Model 2: Bulk Density $\left(\mathrm{kg} / \mathrm{dm}^{3}\right)=1.5688$ $0.0005 \times$ clay $(\mathrm{g} / \mathrm{kg})-0.009 \times$ carbon $(\mathrm{g} / \mathrm{kg})$

Model 3: Bulk Density $\left(\mathrm{kg} / \mathrm{dm}^{3}\right)=1.578$ $0.054 \times$ carbon $(\%)-0.006 \times$ silt $(\%)-0.004$ $\times$ clay $(\%)$

Model 4: Bulk Density $\left(\mathrm{kg} / \mathrm{dm}^{3}\right)=0.69794+$ 0.750636 Exp $[-0.230355$ x OC $(\%)]+$ $[0.0008687 \times$ sand $(\%)]+[0.0005164 \times$ clay $(\%)$ ]

Model 5: Bulk Density $\left(\mathrm{kg} / \mathrm{dm}^{3}\right)=1.66$ $0.308(\mathrm{OC})^{0.5}$

Model 6: Bulk Density $\left(\mathrm{kg} / \mathrm{dm}^{3}\right)=0.167 \mathrm{x}$ $1.526 /\{1.526 \times$ OM $(\%)+0.159[1-\mathrm{OM}$ $(\%)] / 100)\}$

\section{Calculation of SOC stock}

SOC stocks were calculated for each mapping unit using analytical data of associated soil series in mapping units using following formula:

SOC stock $\left(\mathrm{t} C\right.$ ha $\left.^{-1}\right)=$ depth $(\mathrm{m}) \mathrm{x}$ bulk density $\left(\mathrm{Mg} \mathrm{cm}{ }^{-3}\right)$ x OC $\left(\mathrm{g} \mathrm{kg}^{-1}\right)$

The observed SOC stocks were categorized in five groups $(0-10,11-25,26-50,51-100$ and $101-160 \mathrm{t} \mathrm{C} \mathrm{ha}^{-1}$ ) for the state. The present study has been aimed at SOC stock mapping for assessment of SOC stocks under 
different land uses of Uttarakhand state. The soil layer developed in Soil Resource mapping survey developed using remote sensing (RS) technique in GIS software Arc-GIS 10.3 was used as base for preparing SOC stock map.

\section{Results and Discussion}

\section{Comparison of models for bulk density determination}

The plotted graphs of estimated bulk density against observed bulk density observed best $\mathrm{R}^{2}$ value for agriculture (0.811) for pedotransfer function "model 2" equation whereas "model 1" observed best $\mathrm{R}^{2}$ value (0.702) for forest land use (Figure 2 and 3). Therefore "model 2" was selected for estimation of bulk density in agriculture landuse while "model 1" was used for estimation of bulk density in forest, plantation and open scrub land uses. The inconsistency in performance of pedotransfer function models for bulk density models for different land use systems. These results supports the findings of various studies which supports the evaluation of these pedotransfer function models due to their difference in performance under different land conditions (Nanko et al., 2014; Han et al., 2012; Jalabert et al., 2010; Martin et al., 2009)

\section{SOC stock in Uttarakhand state}

Among different classes of SOC stock, the maximum area of $22,46,367$ ha was covered under SOC stock class of $51-100 \mathrm{t} \mathrm{C} \mathrm{ha}^{-1}$ followed by SOC stock classes of $26-50 \mathrm{t} \mathrm{C}$

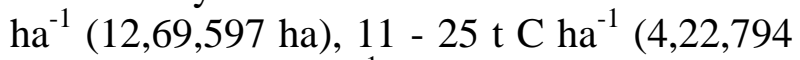
ha), $101-160 \mathrm{t} \mathrm{C} \mathrm{ha}^{-1}(1,73,488 \mathrm{ha})$ and $0-10$ t C ha ${ }^{-1}$ (36,092 ha), respectively (Table 1 and Figure 4).

\section{SOC stock in different districts}

The SOC stock class of $51-100 \mathrm{t} \mathrm{C} \mathrm{ha}^{-1}$ was the dominant class in the eight out of thirteen districts of Uttarakhand state (except Bageshwar, Champawat, Haridwar, Nainital and Udham Singh Nagar districts) covering an area of $42.00 \%$ and $30.60 \%$ area out of total geographical area and total surveyed area, respectively (Table 1 and Figure 4). The districts covering the mountainous area of state observed higher SOC stocks due to having majority of area under forests and open scrub which have higher SOC content as compared to agriculture soils.

\section{SOC stock under different landuse systems}

The landuse systems of forest and grassland/open-scrub observed to have majority of area having SOC stock more than $51 \mathrm{t} \mathrm{C} \mathrm{ha}^{-1}$ (72.65\% of forest area and $77.70 \%$ area under grassland/open-scrub) as compared to agriculture where $81.44 \%$ area was recorded to have less than $50 \mathrm{t} \mathrm{C} \mathrm{ha}^{-1} \mathrm{SOC}$ stock (Table 2). These results are in agreement with literature that the forest and grasslands have higher potential of accumulating and conserving SOC as compared to agriculture as the change in landuse from forest and grassland to agriculture is accompanied by loss in SOC (Kassa et al., 2017; Martín et al., 2016; Poeplau and Don, 2013; Kuimi et al., 2016).

The occurrence of higher SOC content in both forest and grassland/open-scrub can be attributed to the litter fall addition from trees and shrubs to the surface soil (Yimer et al., 2015; Worku et al., 2014 and Nsabimana et al., 2008) Furthermore, the forest and grassland/open-scrub possess a higher organic carbon; through dead fine tree and shrub roots and the mycorrhizal fungi contribution of organic matter (Yimer et al., 2007 and Lemma et al., 2006). Whereas, the low carbon stocks were observed in agriculture land-use as soils in these area are subjected to continuous loss of SOC due to frequent soil disturbance, crop uptake, leaching and surface erosion losses, and inadequate land management. 
Table.1 District wise area distribution of SOC stocks in Uttarakhand state

\begin{tabular}{|c|c|c|c|c|c|c|c|c|c|c|}
\hline \multirow[t]{3}{*}{ Districts } & \multicolumn{10}{|c|}{ Area (ha) } \\
\hline & \multicolumn{5}{|c|}{ SOC stock $(\mathrm{t} \mathrm{C} \mathrm{ha-1)}$} & \multicolumn{4}{|c|}{ Miscellaneous } & \multirow[b]{2}{*}{ Total area } \\
\hline & $0-10$ & $11-25$ & $26-50$ & $51-100$ & $101-160$ & Habitation & Rockout Crop & Snow Cover & Waterbodies & \\
\hline Almora & 783 & 5003 & 108225 & 191482 & 704 & 1184 & - & - & 3065 & 310446 \\
\hline Bageshwar & - & 36554 & 78952 & 73923 & 9807 & 65 & - & 27338 & 738 & 227377 \\
\hline Chamoli & - & 11640 & 75603 & 321865 & 49652 & 34 & 173 & 314754 & 2893 & 776613 \\
\hline Champawat & 6388 & 17283 & 85910 & 59250 & 1758 & 183 & 217 & - & 6978 & 177967 \\
\hline Dehradun & - & - & 59119 & 222780 & 1041 & 9960 & - & - & 11973 & 304872 \\
\hline Haridwar & 4556 & 161560 & 33004 & 15553 & - & 6981 & - & - & 15424 & 237078 \\
\hline Nainital & 9998 & 78329 & 170915 & 135924 & - & 876 & - & - & 16065 & 412106 \\
\hline Pauri Garhwal & 14367 & 54095 & 215584 & 228845 & 867 & 53 & - & - & 14719 & 528530 \\
\hline Pithoragarh & - & 10435 & 40976 & 378684 & 34795 & 674 & 950 & 254047 & 3366 & 723927 \\
\hline Rudraprayag & - & 737 & 28940 & 134810 & 2813 & 19 & - & 31011 & 1210 & 199541 \\
\hline Tehri Garhwal & - & 3156 & 125911 & 198875 & 33929 & 239 & - & 24126 & 4020 & 390258 \\
\hline Udham Singh Nagar & - & 38181 & 187283 & 5841 & - & 5310 & - & - & 17571 & 254188 \\
\hline Uttarkashi & - & 5820 & 59176 & 278533 & 38122 & 139 & - & 420265 & 3421 & 805477 \\
\hline Total Area & \multicolumn{5}{|c|}{4148338} & \multicolumn{4}{|c|}{1200040} & 5348379 \\
\hline
\end{tabular}


Table.2 Distribution of SOC stocks with respect to landuse in Uttarakhand state

\begin{tabular}{|c|c|c|c|c|c|c|}
\hline \multirow[t]{2}{*}{ Landuse } & \multicolumn{5}{|c|}{ SOC stock (t C ha $\left.{ }^{-1}\right)$} & \multirow{2}{*}{$\begin{array}{l}\text { Total Area } \\
\text { (ha) }\end{array}$} \\
\hline & $0-10$ & $11-25$ & $26-50$ & $51-100$ & $101-160$ & \\
\hline Agriculture & 11203 & 208797 & 690352 & 206511 & 1041 & 1117904 \\
\hline Forest & 24889 & 202786 & 413894 & 1541592 & 162687 & 2345847 \\
\hline $\begin{array}{l}\text { Grassland/Open- } \\
\text { scrub }\end{array}$ & - & 4158 & 141117 & 496868 & 9761 & 651903 \\
\hline Plantation & - & 7053 & 24235 & 1395 & - & 32683 \\
\hline Habitation & & & & & & 25717 \\
\hline Rockout Crop & & & & & & 1340 \\
\hline Snow Cover & & & & & & 1071541 \\
\hline Waterbodies & & & & & & 101443 \\
\hline Total Area (ha) & 36092 & 422794 & 1269597 & 2246367 & 173488 & 5348379 \\
\hline
\end{tabular}

Fig.1 Location map of Uttarakhand state

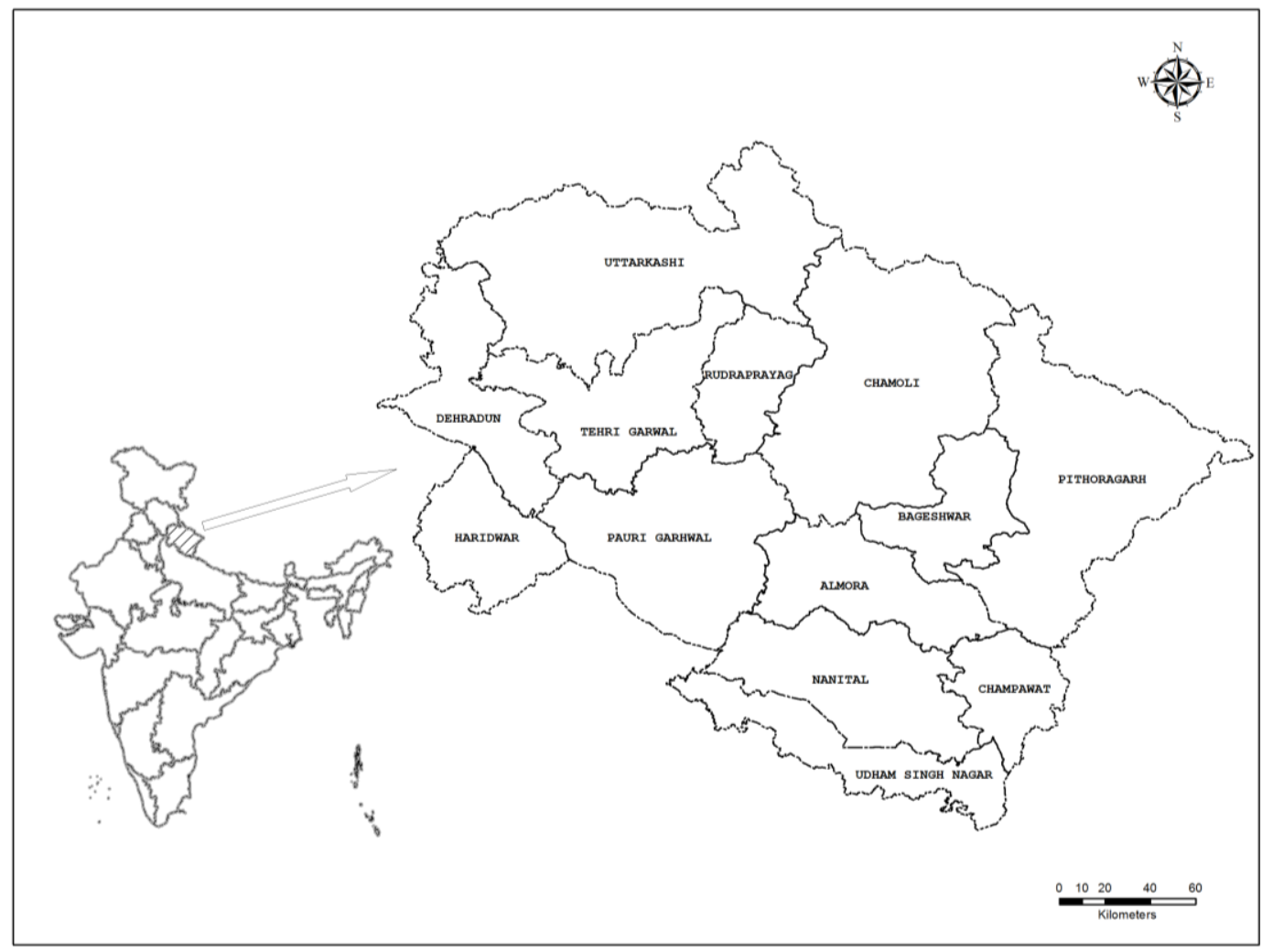


Fig.2 Validation of models for predicting bulk density of agriculture land use

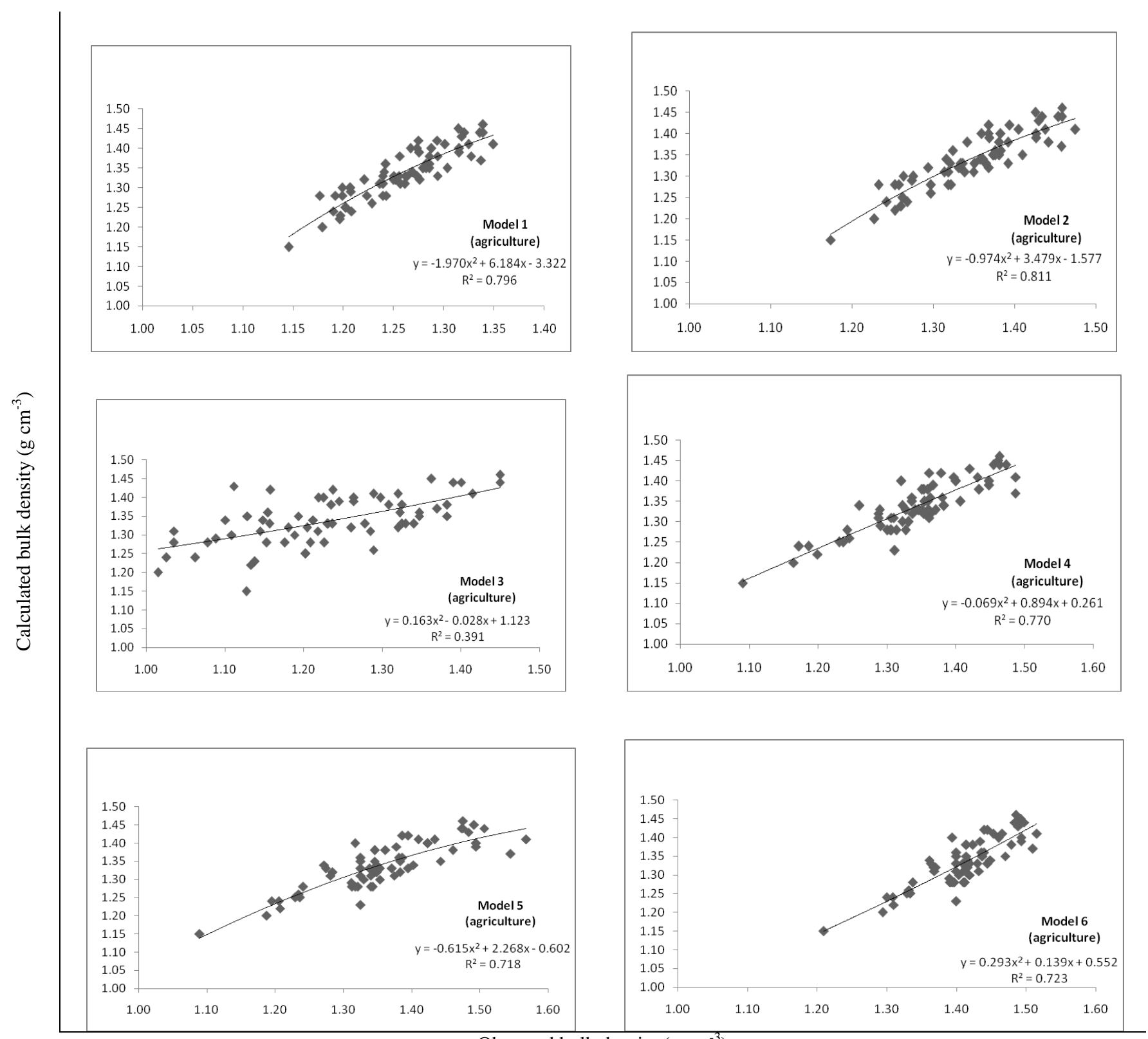

Observed bulk density $\left(\mathrm{g} \mathrm{cm}^{-3}\right)$ 
Fig.3 Validation of models for predicting bulk density of forest landuse

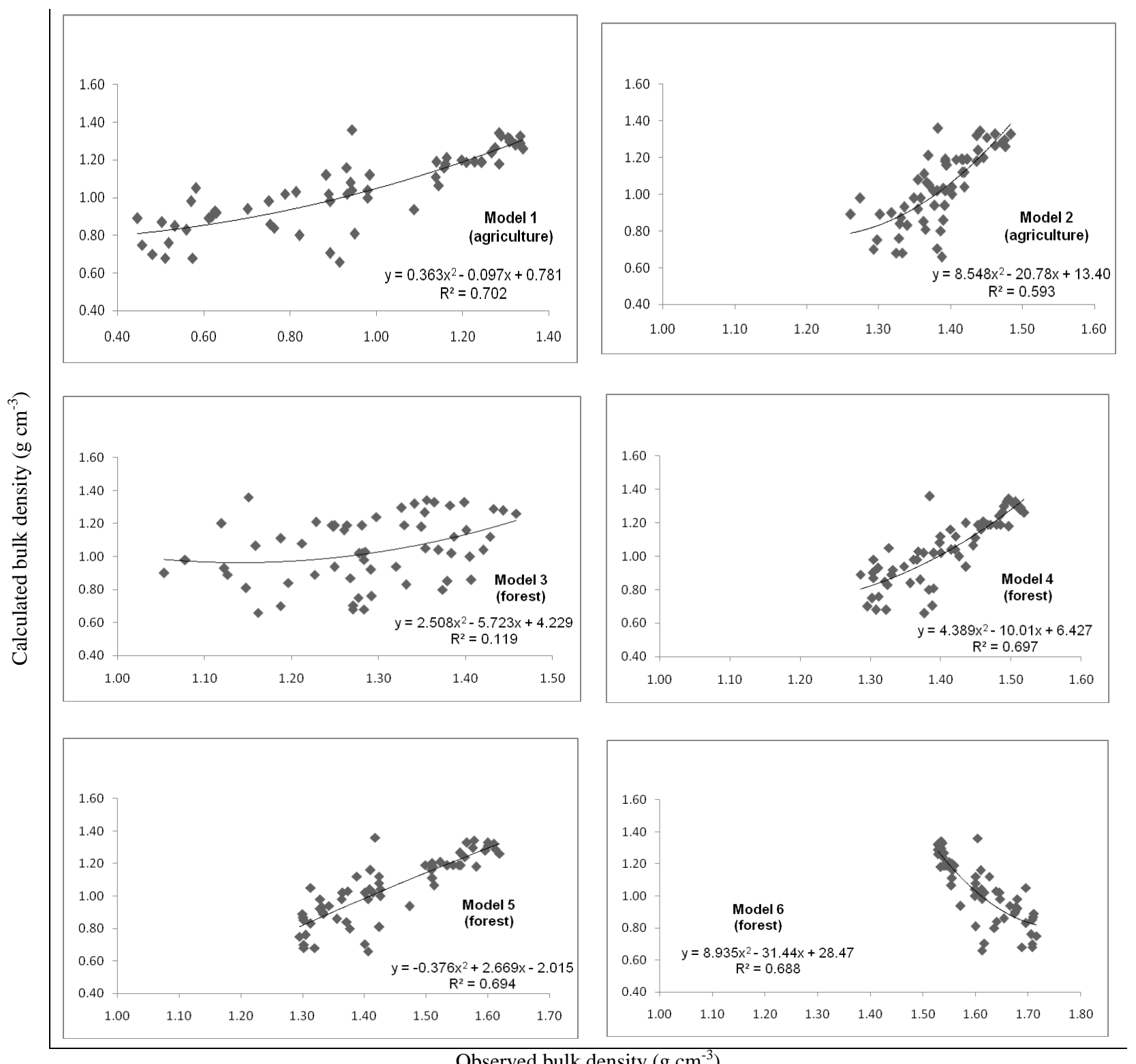

Observed bulk density $\left(\mathrm{g} \mathrm{cm}^{-3}\right)$ 
Fig.4 Spatial distribution of SOC stock classes in Uttarakhand state

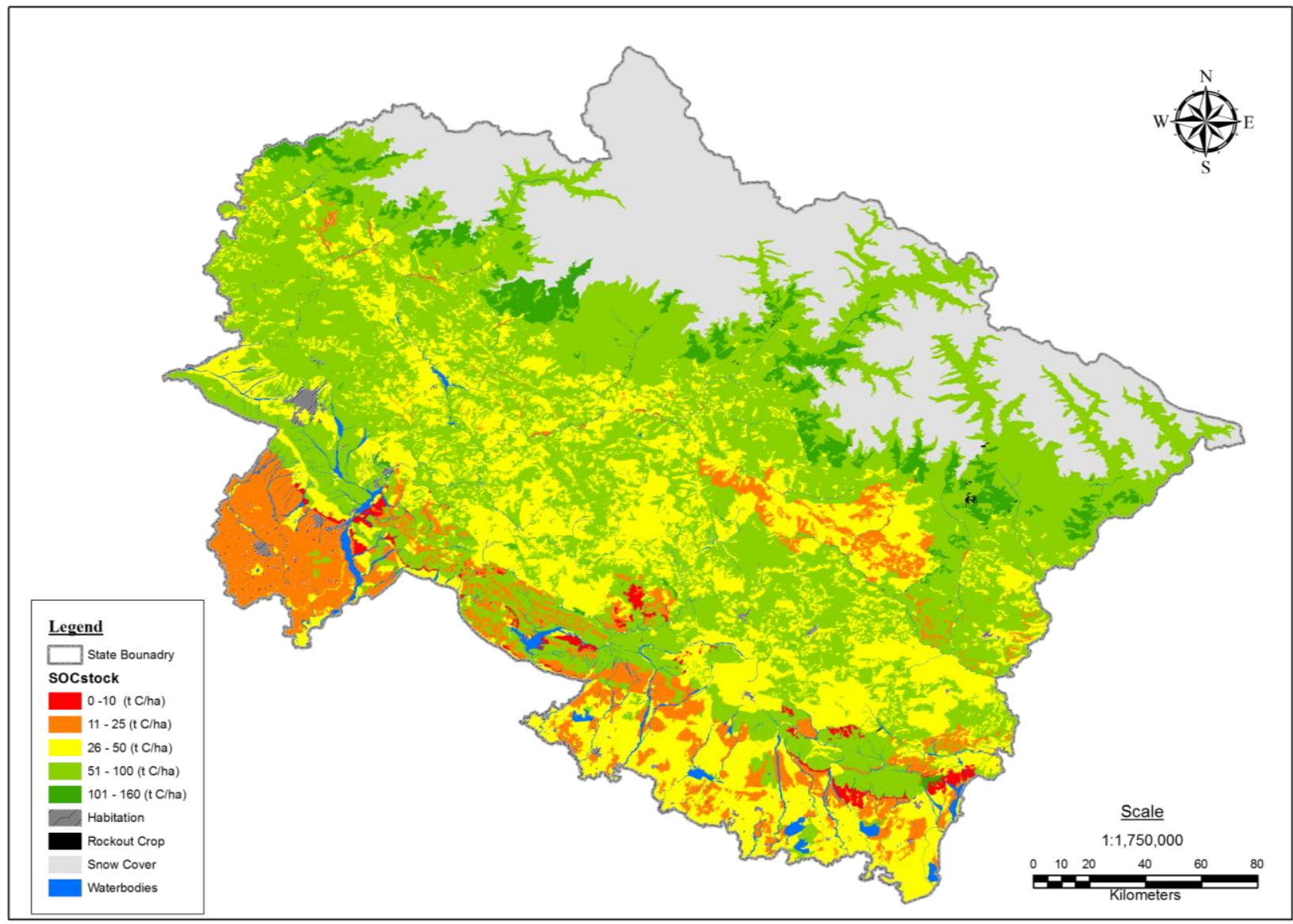

The crop residue removal and grazing after the harvest and are found in concordance with the findings of Don et al., (2011) and Lemenih and Itanna (2004).

The majority of the forest and grassland/openscrub lies with in the mountainous region of the state and are generally subjected to higher risk of soil erosion due to higher degree of slopes. However, these areas are also reported to have higher risk of soil loss through erosion due to higher degree of land slope and high rainfall and are subjected to frequent occurrences of landslides every year (Mahapatra et al., 2018).

In conclusion, present study demonstrated the application of random sampling for the estimation of bulk density for estimating SOC stocks across landscapes in mountainous areas. The method applied is simple and allows for reliable and robust measurements of soil carbon stocks in different soil types and under different land cover and land-use systems. Furthermore, this study also confirms that the performance of pedotransfer function in assessment of bulk density varies with the type of land use system.

The land use wise distribution revealed that the forests and grasslands are the major contributor toward the state SOC stock as $72.65 \%$ of forest area and $77.70 \%$ area under grassland /open-scrub were found to have SOC stock above $50 \mathrm{t} \mathrm{C}^{-1}$, while majority of these area lies in mountainous region of state and subjected to high risk of soil erosion. Therefore, such area requires special attention for management and conservation of these SOC stocks. 
This study has generated the SOC stock database and its spatial distribution in the state which can be taken as base line information for future monitoring of SOC stocks.

\section{Acknowledgement}

Authors want to record their thanks to Natural Resource Management Division, Department of Agriculture Co-operation and Farmer's Welfare, Ministry of Agriculture and Farmer's Welfare, Govt. of India for providing all necessary facilities and financial support to carry out this study.

\section{References}

Abdelbaki, A.M., 2016. Evaluation of pedotransfer functions for predicting soil bulk density for US soils. Ain Shams Engineering Journal. Online published: https://www.sciencedirect. com/science/article/pii/S209044791630 1745 .

Benites, V.M., Machado, P.L.O.A., Fidalgo, E.C.C., Coelho, M.R. and Madari, B.E., 2007. Pedotransfer functions for estimating soil bulk density from existing soil survey reports in Brazil. Geoderma. 139: 90-97.

Bernoux, M., Cerri, C., Arrouays, D., Jolivet, C., and Volkoff, B. 1998. Bulk densities of Brazilian Amazon soils related to other soil properties. Soil Science Society of America Journal. 62(3): 743749.

Black, C.A. 1965. Soil plant relationship. $2^{\text {nd }}$ edition Pub. NewYork., USA, pp. 515516.

Bouyoucos, G.J.1962. Hydrometer method improved for making particle size analysis of soils. Agronomy Journal. 54: 464-465.

Chaudhari, P.R., Ahire, D.V., Ahire, V.D., Chkravarty, M. and Maity, S. 2013. Soil bulk density as related to soil texture, organic matter content and available total nutrients of Coimbatore soil. International Journal of Scientific and Research Publications. 3(2): 1-8.

Don, A., Schumacher, J., and Freibauer, A. 2011. Impact of tropical land use change on soil organic carbon stocks-a meta analysis. Global Change Biology. 17(4): 1658-1670.

Global Climate Report - Annual. 2017. National Centers for Environmental Information (NCEI). https://www.ncdc. noaa.gov/sotc/global/201713.

Han, G.Z., Zhang, G.L., Gong, Z.T., and Wang, G.F. 2012. Pedotransfer functions for estimating soil bulk density in China. Soil Science. 177(3): 158-164.

Martin, M.P., Seen, D.L., Boulonne, L., Jolivet, C., Nair, K.M., Bourgeon, G. and Arrouays, D. 2009. Optimizing pedotransfer functions for estimating soil bulk density using boosted regression trees. Soil Science Society of America Journal. 73 (2): 485-493.

Jackson, M.L. 1973. Soil Chemical Analysis. Prentice Hall of India Pvt. Ltd., New Delhi, pp. 38-56.

Jalabert, S.S.M., Martin, M.P., Renaud, J.P., Boulonne, L., Jolivet, C., Montanarella, L. and Arrouays D. 2010. Estimating forest soil bulk density using boosted regression modelling. Soil Use and Management. 26(4): 516-528.

Kassa, H., Dondeyne, S., Poesen, J., Frankl, A. and Nyssen, J. 2017. Impact of deforestation on soil fertility, soil carbon and nitrogen stocks: the case of the Gacheb catchment in the White Nile Basin, Ethiopia. Agriculture, Ecosystems and Environment. 247: 273-282.

Kaur, R., Kumar, S. and Gurung, H.P. 2002. A pedo-transfer function (PTF) for estimating soil bulk density from basic 
soil data and its comparison with existing PTFs. Soil Research. 40(5): 847-858.

Kuimi, T., Vashum and Shanmuganathan, J. 2016. Soil organic carbon status and sustainability of slash-and-burn cultivation in India. Journal of Sustainable Forestry. 35(8): 591-603.

Kumar, D., Bansal, M.L., Phogat, V.K. 2009. Compactability in relation to texture and organic matter content of alluvial soils. Indian Journal of Agricultural Research. 43(3): 180-186.

Lal, R. 2004. Soil carbon sequestration impacts on global climate change and food security. Science. 304: 1623-1627.

Lal, R. 2001. World cropland soils as a source or sink for atmospheric carbon. Advances in Agronomy. 71: 145-191.

Leifeld, J., Bassin, S., and Fuhrer, J. 2005. Carbon stocks in Swiss agricultural soils predicted by land-use, soil characteristics, and altitude. Agriculture, Ecosystems \& Environment. 105(1-2): 255-266.

Lemenih, M. and Itanna, F. 2004. Soil carbon stocks and turnovers in various vegetation types and arable lands along an elevation gradient in southern Ethiopia. Geoderma. 123(1-2): 177-188.

Lemma, B., Kleja, D.B., Nilsson, I. and Olsson, M. 2006. Soil carbon sequestration under different exotic tree species in the southwestern highlands of Ethiopia. Geoderma. 136(3-4): 886-898.

Mahapatra, S. K., Reddy, G.O., Nagdev, R., Yadav, R.P., Singh, S.K., and Sharda, V.N. 2018. Assessment of soil erosion in the fragile Himalayan ecosystem of Uttarakhand, India using USLE and GIS for sustainable productivity. Current Science. 115(1): 108-121.

Martín, J.R., Álvaro-Fuentes, J., Gonzalo, J., Gil, C., Ramos-Miras, J.J., Corbí, J.G., and Boluda, R. 2016. Assessment of the soil organic carbon stock in Spain. Geoderma. 264: 117-125.

Morisada, K., Ono, K. and Kanomata, H. 2004. Organic carbon stock in forest soils in Japan. Geoderma. 119(1-2): 2132.

Nanko, K., Ugawa, S., Hashimoto, S., Imaya, A., Kobayashi, M., Sakai, H., Ishizuka, S., Miura, S., Tanaka, N., Takahashi, M. and Kaneko, S. 2014. A pedotransfer function for estimating bulk density of forest soil in Japan affected by volcanic ash. Geoderma. 213: 36-45.

Nsabimana, D., Klemendtson, L., Kaplin, B.A. and Wallin, G. 2008. Soil carbon and nutrient accumulation under forest plantations in southern Rwanda. African Journal of Environmental Science and Technology. 2(6): 142-149.

Poeplau, C. and Don, A. 2013. Sensitivity of soil organic carbon stocks and fractions to different land-use changes across Europe. Geoderma. 192: 189-201.

Sakin, E. 2012. Organic carbon organic matter and bulk density relationships in arid-semi arid soils in Southeast Anatolia region. African Journal of Biotechnology. 11(6):1373-1377.

Sakin, E., Deliboran, A. and Tutar, E. 2011. Bulk density of Harran plain soils in relation to other soil properties. African Journal of Agricultural Research. 6(7): 1750-1757.

Tomasella, J. and Hodnett, M.G. 1998. Estimating soil water retention characteristics from limited data in Brazilian Amazonia. Soil Science. 163(3): 190-202.

Worku, G., Bantider, A. and Temesgen, H. 2014. Effects of land use/land cover change on some soil physical and chemical properties in Ameleke microwatershed Gedeo and Borena Zones, South Ethiopia. Journal of Environment and Earth Science. 4: 13-24. 
Xu, L., He, N.P., Yu, G.R., Wen, D., Gao, Y. and He, H.L. 2015. Differences in pedotransfer functions of bulk density lead to high uncertainty in soil organic carbon estimation at regional scales: Evidence from Chinese terrestrial ecosystems. Journal of Geophysical Research: Biogeosciences. 120(8): 1567-1575.

Yimer, F., Alemu, G. and Abdelkadir, A. 2015. Soil property variations in relation to exclosure and open grazing land use types in the Central Rift Valley area of Ethiopia. Environmental Systems Research. 4: 17.

Yimer, F., Ledin, S. and Abdelkadir, A. 2007. Changes in soil organic carbon and total nitrogen contents in three adjacent land use types in the Bale Mountains, southeastern highlands of Ethiopia. Forest Ecology and Management. 242(2-3): $337-342$.

\section{How to cite this article:}

Nitin Surendra Singh Gahlod, Navneet Jaryal, Mallikarjun Roodagi, Sanjay A. Dhale, Devinder Kumar and Ravindra Kulkarni. 2019. Soil Organic Carbon Stocks Assessment in Uttarakhand State using Remote Sensing and GIS Technique. Int.J.Curr.Microbiol.App.Sci. 8(01): 16461658. doi: https://doi.org/10.20546/ijcmas.2019.801.173 